\title{
ANIMAL RESEARCH PAPER Performance of crossbred dairy Friesian calves fed two levels of Saccharomyces cerevisiae: intake, digestion, ruminal fermentation, blood parameters and faecal pathogenic bacteria
}

\author{
A. A. HASSAN ${ }^{1}$, A. Z.M. SALEM ${ }^{2 *}$, A. E. KHOLIF ${ }^{3}$, M. SAMIR ${ }^{1}$, M. H. YACOUT ${ }^{1}$, \\ S. H. ABU HAFSA ${ }^{4}$, G. D. MENDOZA ${ }^{5}$, M. M. Y. ELGHANDOUR ${ }^{2}$, M. AYALA ${ }^{6}$ AND S. LOPEZ $^{7}$ \\ ${ }^{1}$ Animal Production Research Institute, Ministry of Agriculture, Dokki, Giza, Egypt \\ ${ }^{2}$ Facultad de Medicina Veterinaria y Zootecnia, Universidad Autónoma del Estado de México, Toluca, México \\ ${ }^{3}$ Dairy Science Department, National Research Centre, 33 Bohouth St. Dokki, Giza, Egypt \\ ${ }^{4}$ Livestock Research Department, Arid Lands Cultivation Research Institute, City of Scientific Research and Technological \\ Applications, New Borg El-Arab, P. O. Box: 21934 Alexandria, Egypt \\ ${ }^{5}$ Universidad Autónoma Metropolitana, Unidad Xochimilco, México \\ ${ }^{6}$ Universidad Autónoma del Estado de Hidalgo, Instituto de Ciencias Agropecuarias, Área Académica de Medicina \\ Veterinaria y Zootecnia, Rancho Universitario Av. Universidad Km 1 Ex-Hda de Aquetzalpa, A.P. 32, CP 43600, México \\ ${ }^{7}$ Departamento de Producción Animal, Instituto de Ganadería de Montaña (IGM) CSIC-Universidad de León, Universidad \\ de León, E-24071 León, Spain
}

(Received 15 October 2015; revised 23 May 2016; accepted 8 July 2016)

\section{SUMMARY}

The effect of feeding two levels of Saccharomyces cerevisiae on the performance of crossbred Friesian calves was investigated. Twenty-four neonatal male Friesian $\times$ Baladi calves $(35 \cdot 5 \pm 0 \cdot 25 \mathrm{~kg}$ of initial body weight) were randomly assigned in a completely randomized design into three experimental groups for 90 days (eight calves per group). Calves fed their diets without yeast (S. cerevisiae) were considered as Control, while the diets of other calves were supplemented daily either with $2.5 \mathrm{~g}$ (YL diet) or with $5 \mathrm{~g}$ (YH diet) of yeast per calf. Calves fed the $\mathrm{YH}$ diet showed increased feed intake, while dry matter and fibre digestibilities were increased in calves fed $\mathrm{YH}$ and $\mathrm{YL}$ diets. Calves fed $\mathrm{YL}$ and $\mathrm{YH}$ diets showed lower ruminal ammonia- $\mathrm{N}$ and higher total volatile fatty acids, acetate and propionate concentrations than Control calves. Both $\mathrm{YH}$ and $\mathrm{YL}$ calves showed increased plasma concentrations of total protein, globulin and glucose and decreased cholesterol and triglycerides concentrations. Calves' final weight and daily gain were increased with $S$. cerevisiae yeast supplemented diets. After 42 days of experiment, Clostridium spp., Escherichia coli and Enterobacteria spp. counts were down to undetectable levels in the faeces of calves fed S. cerevisiae additive. It could be concluded that adding S. cerevisiae to milk-fed calves increased feed utilization and improved pre-weaned calf performance and health status, reducing faecal pathogenic bacteria.

\section{INTRODUCTION}

One of the major challenges facing the animal production industry in developing countries is to improve efficiency of production and to maintain feed utilization. Many attempts have been made by researchers to overcome these challenges, such as including the incorporation of antimicrobials and other

* To whom all correspondence should be addressed. Email: asalem70@yahoo.com natural products into animal feeds (Ahmed et al. 2015; Rojo et al. 2015; Morsy et al. 2016). Feed additives of microbial origin, ionophores and antibiotics have become a common practice in ruminant nutrition; however, most studies have been conducted with lactating cows or in vitro, with few studies on pre-weaned calves. The European Union banned the sub-therapeutic use of antibiotics and ionophores as additives in animal feed since 2006 as it can increase antimicrobial- and antibiotic resistance in bacteria 
(Langford et al. 2003), thus increasing the risk of human infections with antibiotic-resistant bacteria (Phillips et al. 2004). Moreover, the use of antimicrobials in animal feed may cause the appearance of their residues and metabolites in milk and meat, raising safety concerns for consumers (Russell \& Houlihan 2003). Therefore, there is an increasing interest in promoting the use of alternative feed additives to modify rumen fermentation and improve feed utilization (Cedillo et al. 2014; Salem et al. 2014).

Saccharomyces cerevisiae live yeast is a microbial alternative to antimicrobial feed additives that could enhance health and performance of young calves (Magalhães et al. 2008). It has been generally recognized as safe for human consumption, and considered safe when used in animal feed. Saccharomyces cerevisiae added at $20 \mathrm{~g} / \mathrm{kg}$ dry matter (DM) to cereal grains fed to new-born calves increased grain intake and affected rumen development, but no effects were observed at a rate of addition of $10 \mathrm{~g} / \mathrm{kg}$ DM of cereal grains (Lesmeister et al. 2004). Feeding live $S$. cerevisiae to new-born lambs has been observed to result in faster establishment of cellulolytic bacteria (Chaucheyras-Durand \& Fonty 2001) and ciliate protozoa (Chaucheyras-Durand \& Fonty 2002) in the rumen, leading to improved feed intake and weight gain.

Gastrointestinal infections, diarrhoea and dehydration are the main health problems in new-born calves, in particular during the pre-weaning period, and can result in high mortality rates. Feeding $S$. cerevisiae, with some immunological properties, may be important in young calves to reduce bacterial, viral and protozoal pathogens that cause digestive tract diseases and disorders (Magalhães et al. 2008). Collectively, feeding $S$. cerevisiae might increase feed intake and energy utilization, enhance the immune response and reduce the incidence of diseases of young calves.

Therefore, the present study aimed to study the effect of feeding live $S$. cerevisiae yeast at low and high daily doses to male crossbred Friesian $\times$ Baladi calves on performance (intake, digestibility, growth) and health status (blood parameters, faecal shedding of pathogenic bacteria) from birth and through the pre-weaning phase.

\section{MATERIALS AND METHODS}

\section{Study location}

The study was carried out at Noubaria Experimental Station, Animal Production Research Institute,
Agriculture Research Center (Egypt). This area has an annual average rainfall of $22 \mathrm{~mm}$ and mean annual temperature between 14 and $32{ }^{\circ} \mathrm{C}$. Calves were cared for and handled in accordance with the Guide for the Care and Use of Agricultural Animals in Agricultural Research and Teaching (FASS 2010).

\section{Calves, feeding and management}

Twenty-four neonatal male crossbred Friesian $\times$ Baladi calves $(35.5 \pm 0 \cdot 25 \mathrm{~kg}$ initial body weight (BW) at birth) with no congenital problems were randomly allocated to three experimental groups with eight calves each. At birth (day 0), calves were weighed and removed from their dams within $1-2 \mathrm{~h}$ of calving and randomly allocated to one of the experimental treatments. Calves were identified with ear tags and kept in individual pens with a covered area $\left(2 \times 1.5 \mathrm{~m}^{2} /\right.$ calf $)$, with identical direction and orientation, and equipped with similar troughs for feed and water. From day 0 to 3, each calf was bottle-fed 4 litres of whole colostrum obtained from its mother at three feeding times. From day 4 until the end of the experiment at day 90, calves were fed whole cow's milk twice daily at 07:00 and 18:00 h. The daily amount of milk fed was the same for all calves, and was varied weekly throughout the experiment (all values are per calf and per day): 4 litres in week 1, 4.5 litres in week 2, 5 litres in week 3, 5.5 litres in week 4, 6 litres in week 5, 5.5 litres in week 6, 5 litres in week 7, 4.5 litres in week 8, 4 litres in week 9, 3 litres in week 10, 2 litres in weeks 11 and 12 , and 1 litre from day 85 until 90 . The analysed composition of the whole milk was $113 \mathrm{~g}$ of total solids, $31.8 \mathrm{~g}$ of protein, $32.0 \mathrm{~g}$ of fat, $39.6 \mathrm{~g}$ of lactose and $9.7 \mathrm{~g}$ of ash per $\mathrm{kg}$ of milk. Additionally, calves were offered a starter concentrate feed containing (g/kg): 260 soybean meal, 300 maize, 100 barley, 210 wheat bran, 60 linseed cake, 53 gluten, 15 limestone, 2 minerals and vitamins mixture from day 36 to 90 , and fed berseem hay (Trifolium alexandrinum) from day 57 to 90. Chemical composition of the starter concentrate feed and the berseem hay fed to the calves is shown in Table 1. The amount of concentrate fed to each calf was $250 \mathrm{~g} /$ day during week 6 and $400 \mathrm{~g} /$ day during week 7 , and thereafter the concentrate was offered ad libitum until the end of the experiment. Similarly, during weeks 9 and 10 the amount of hay fed was restricted to $100 \mathrm{~g} /$ day for each calf, and subsequently the hay was offered ad libitum until the 
Table 1. Chemical composition ( $\mathrm{g} / \mathrm{kg}$ of dry matter unless otherwise stated) of calf starter concentrate and berseem hay

\begin{tabular}{lll}
\hline \hline & $\begin{array}{l}\text { Calf starter } \\
\text { concentrate* }^{*}\end{array}$ & $\begin{array}{l}\text { Berseem } \\
\text { hay }\end{array}$ \\
\hline Dry matter (g/kg wet material) & 887 & 877 \\
Organic matter & 935 & 927 \\
Crude protein & 209 & 122 \\
Ether extract & 47 & 13 \\
Crude fibre & 79 & 246 \\
Crude ash & 65 & 73 \\
Non-fibre carbohydratest & 542 & 362 \\
Neutral detergent fibre & 226 & 432 \\
Acid detergent fibre & 82 & 307 \\
\hline \hline
\end{tabular}

* Calf starter concentrate contained (g/kg): 260 soybean meal, 300 maize, 100 barley, 210 wheat bran, 60 linseed cake, 53 gluten, 15 limestone, 2 minerals and vitamins mixture.

+ Non-fibre carbohydrates calculated by difference (1000 (neutral detergent fibre + crude protein + ether extract + ash)).

end of the experiment. Starter concentrate and berseem hay were fed twice daily at $08: 00$ and $19: 00 \mathrm{~h}$, starting with the concentrate feed followed by the hay. During the whole experimental period (i.e. from day 4 until 90), S. cerevisiae daily doses were added to and thoroughly mixed with the whole milk fed in the morning meal. Calves were fed according to the National Research Council (2001) recommendations. Fresh water was offered ad libitum to all the calves. Individual calf feed intake, weight gain and health were monitored.

Calves were fed milk without $S$. cerevisiae (Control diet) or with a daily addition of thermostable YeaSacc $^{\circledR} 1026$ live yeast containing a minimum of $5 \times 10^{9}$ colony forming units (CFU) of $S$. cerevisiae/g DM live yeast (BGY-35, F.L. Emmert Company, Cincinnati, $\mathrm{OH}, \mathrm{USA})$. The $S$. cerevisiae was added to provide daily doses of either $2.5 \mathrm{~g}$ (YL diet) or $5 \mathrm{~g}$ (YH diet) per calf for the whole duration of the experiment (90 days). Daily intakes of milk, starter concentrate and berseem hay were recorded by weighing the offered amounts of each feed and the refusals from the previous day. For daily weight gain calculations, calves were weighed in a digital multi-purpose platform scale (PS-2000 Platform Scale, Salter Brecknell, Fairmont, MN, USA) at 14-day intervals during the experimental period.
During the last 7 days of the experiment, faecal grab samples were collected from all calves twice daily at $07: 00$ and $15: 00 \mathrm{~h}$, dried at $60^{\circ} \mathrm{C}$ in a forced-air oven for $48 \mathrm{~h}$ and pooled by calf (resulting in a composite sample per calf). Acid-insoluble ash was used as an internal indigestible marker, where digestibility coefficients were calculated according to the method of Ferret et al. (1999).

Dried feed (starter concentrate and berseem hay), feed orts and faecal samples were ground through a $1 \mathrm{~mm}$ screen using a Wiley mill (Arthur H. Thomas, Philadelphia, PA, USA), and analysed according to the AOAC (1997) official methods for DM (method \#930.15), ash (method \#942.05), N (method \#954.01) and ether extract (EE; method \#920.39). Neutral detergent fibre (NDF) and acid detergent fibre (ADF) were analysed according to the method of Van Soest et al. (1991). Non-fibre carbohydrates and organic matter (OM) were calculated. Milk samples were analysed for total solids, protein, fat and lactose contents using infrared spectrophotometry (Foss 120 Milko-Scan, Foss Electric, Hillerød, Denmark), while ash content was determined after incinerating a milk sample in a muffle furnace at $550{ }^{\circ} \mathrm{C}$ for $8 \mathrm{~h}$.

\section{Sampling and analysis of rumen fluid}

As described in Kholif et al. (2015), on the last day of the experiment (i.e. day 90), ruminal contents were sampled at 0,3 and $6 \mathrm{~h}$ post-morning feeding to determine the $\mathrm{pH}$ and concentration of fermentation end-products. About $100 \mathrm{ml}$ of rumen content was collected once at each sampling time from the ventral sac by using a stomach tube, and then the sample taken from each calf was strained through four layers of cheesecloth. The $\mathrm{pH}$ of ruminal fluid was measured immediately after collection using a $\mathrm{pH}$ meter (Orion ${ }^{\mathrm{TM}}$ Star A211 pH Benchtop Meter, Thermo Scientific, Beverly, MA, USA).

A sub-sample of $5 \mathrm{ml}$ was preserved in $5 \mathrm{ml}$ of $0 \cdot 2 \mathrm{M}$ hydrochloric acid $(\mathrm{HCl})$ for ammonia- $\mathrm{N}$ analysis according to the method of AOAC (1997). Additionally, a sample of $0.8 \mathrm{ml}$ of rumen fluid was mixed with $0.2 \mathrm{ml}$ of a solution containing $250 \mathrm{~g}$ of metaphosphoric acid/litre for total volatile fatty acids (VFA) analysis. Samples collected at $3 \mathrm{~h}$ post-feeding were analysed for the individual VFA concentrations. Total VFA concentration in samples were determined by titration, after steam distillation of a sample according to the method of Annison (1954). According to the 
method of García-González et al. (2008), concentrations of acetic, propionic and butyric acid were quantified using crotonic acid as the internal standard using gas chromatography (model 5890, Hewlett Packard, Little Falls, DE, USA) with a capillary column $(30 \mathrm{~m}$ length $\times 0.25 \mathrm{~mm}$ internal diameter (i.d.), $1 \mathrm{~m}$ phase thickness, Supelco Nukol; SigmaAldrich, Mississauga, ON, Canada).

\section{Sampling and analysis of blood serum}

On the last day of the experiment (i.e. day 90), blood samples $(10 \mathrm{ml})$ were taken in the morning $(4 \mathrm{~h}$ after starter concentrate and hay feeding) from the jugular vein of each calf into a clean dry tube, without anticoagulants and centrifuged at $4000 \times \mathrm{g}$ at $4{ }^{\circ} \mathrm{C}$ for 20 min. Serum was separated into $2-\mathrm{ml}$ clean dried Eppendorf tubes and frozen at $-20^{\circ} \mathrm{C}$ until the analysis. Blood serum samples were analysed for concentrations of total protein, albumin, urea-N, glutamate-oxaloacetate transaminase (GOT), glutamatepyruvate transaminase (GPT), glucose, cholesterol and triglycerides using specific kits (Stanbio Laboratory, Boerne, TX, USA) following the manufacturer's instructions. Globulin concentration was calculated by the difference between the total serum protein and their respective albumin values.

\section{Faecal pathogenic bacterial counts}

A portion of the faecal grab material sampled from each calf was collected in sterile McCartney's bottle and kept in ice. Faecal bacterial counts were determined using the pour plate technique for total Escherichia coli, Clostridium spp. and Enterobacteria spp. colony counts according to the method of Oxoid (1985). For all determined bacterial species, tenfold dilutions were prepared from each faecal sample in peptone water, and then three empty sterile Petri plates were inoculated by transferring 1 $\mathrm{ml}$ from each dilution into the plates. The inoculum was thoroughly mixed with sterile molten agarcontaining media, namely chromogenic coliform medium for $E$. coli, reinforced clostridial medium for Clostridium spp., or Enterobacteria enrichment broth, Mossel medium for Enterobacteriaceae, previously held in a water bath at $50{ }^{\circ} \mathrm{C}$. The agar plates were allowed to be solidified and then incubated at $37^{\circ} \mathrm{C}$ for $24 \mathrm{~h}$. Bacterial colonies were counted in plates using an optical counter.

\section{Statistical analysis}

The experiment was a completely randomized oneway ANOVA design with three treatments (Control, $\mathrm{YL}$ and $\mathrm{YH}$ ) and eight replicates (each calf was considered as an experimental unit) per treatment. The statistical model included the fixed effect of diet $\left(D_{i}\right)$ : $y_{i j}=\mu+D_{i}+\varepsilon_{i j}$, where $y_{i j}$ is each individual observation for a given variable, $\mu$ is the overall mean, and $\varepsilon_{i j}$ is the residual random term. Statistical analyses were performed using PROC MIXED of SAS (SAS Inst. Inc. Cary, NC, USA). The Tukey-Kramer test was used for the multiple comparisons of means, and polynomial (linear and quadratic) contrasts were used to examine the responses to increasing doses of $S$. cerevisiae. Significance was declared at a level of $P<0.05$ and trends when $P \leqslant 0 \cdot 10$.

\section{RESULTS}

Feed intake and digestibility

Calves fed YH diet supplemented with $S$. cerevisiae at the higher level ingested more $(P<0 \cdot 05)$ solid feed (concentrate and hay) than calves fed the Control diet, whereas those eating the $Y L$ diet showed intermediate intakes (Table 2).

Digestibility coefficients were increased $(P<0.05)$ with $S$. cerevisiae supplementation to calves. Dry matter (linear effect, $P=0 \cdot 004$ ), NDF (linear effect, $P<0.001$; quadratic effect, $P=0.013)$ and ADF (linear effect, $P<0.001$; quadratic effect, $P=0.018$ ) digestibilities were increased with both $\mathrm{YL}$ and $\mathrm{YH}$ diets compared with the Control diet. Moreover, with the $\mathrm{YH}$ diet $\mathrm{CP}$ digestibility was increased $(P<$ 0.05) compared with the Control diet (Table 2).

\section{Ruminal fermentation and blood chemistry}

No effect on ruminal $\mathrm{pH}$ was observed when calves received $S$. cerevisiae supplementation either at low or high levels. Compared with the Control diet, with both $\mathrm{YL}$ and $\mathrm{YH}$ diets ruminal ammonia- $\mathrm{N}$ concentrations $(P<0.001)$ were decreased at different times post-feeding. In contrast, supplemented diets $(\mathrm{YL}$ and $\mathrm{YH})$ resulted in increased total VFA concentrations in the rumen at different times post-feeding $(P<$ $0 \cdot 001)$ compared with the Control diet. At $3 \mathrm{~h}$ postfeeding, ruminal acetate $(P=0.030)$ and propionate $(P<0.001)$ concentrations were increased, whereas butyrate concentration $(P=0.025)$ and acetate to 
Table 2. Feed intake and digestibility of diets supplemented with different levels of Saccharomyces cerevisiae to crossbred dairy Friesian calves ( $n=8$ per each group)

\begin{tabular}{|c|c|c|c|c|c|c|c|}
\hline & \multicolumn{3}{|c|}{ Diets* } & \multirow[b]{2}{*}{ S.E.M. } & \multicolumn{3}{|c|}{$P$ value } \\
\hline & Control & $\mathrm{YL}$ & $\mathrm{YH}$ & & $\begin{array}{l}\text { Diet } \\
\text { effects }\end{array}$ & Linear & Quadratic \\
\hline \multicolumn{8}{|l|}{ Feed intake (g/day): } \\
\hline Starter concentrate feed at day 90 & 1197 & 1348 & 1404 & $45 \cdot 2$ & $0 \cdot 027$ & $0 \cdot 009$ & $0 \cdot 390$ \\
\hline Berseem hay at day 90 & 158 & 206 & 212 & $15 \cdot 8$ & $0 \cdot 081$ & $0 \cdot 037$ & $0 \cdot 308$ \\
\hline Total solid feed (concentrate + hay) at day 90 & 1355 & 1554 & 1616 & $53 \cdot 4$ & $0 \cdot 016$ & $0 \cdot 006$ & $0 \cdot 305$ \\
\hline Average concentrate intake from day 36 to 90 & 706 & 781 & 800 & $24 \cdot 9$ & $0 \cdot 060$ & $0 \cdot 023$ & $0 \cdot 381$ \\
\hline Average berseem hay intake from day 57 to 90 & 120 & 144 & 148 & $6 \cdot 6$ & $0 \cdot 030$ & $0 \cdot 013$ & $0 \cdot 240$ \\
\hline \multicolumn{8}{|c|}{ Nutrient digestibility coefficients (g digested/g ingested) } \\
\hline Dry matter & $0 \cdot 54$ & $0 \cdot 58$ & $0 \cdot 59$ & $0 \cdot 072$ & $0 \cdot 008$ & $0 \cdot 004$ & $0 \cdot 124$ \\
\hline Crude protein & $0 \cdot 60$ & $0 \cdot 63$ & $0 \cdot 63$ & $0 \cdot 059$ & $0 \cdot 032$ & 0.015 & $0 \cdot 291$ \\
\hline Neutral detergent fibre & $0 \cdot 38$ & $0 \cdot 46$ & $0 \cdot 46$ & $0 \cdot 075$ & $<0 \cdot 001$ & $<0 \cdot 001$ & $0 \cdot 013$ \\
\hline Acid detergent fibre & $0 \cdot 34$ & $0 \cdot 41$ & $0 \cdot 41$ & $0 \cdot 073$ & $0 \cdot 001$ & $<0 \cdot 001$ & $0 \cdot 018$ \\
\hline
\end{tabular}

* Saccharomyces cerevisiae added at $0 \mathrm{~g} /$ calf/day (Control), $2 \cdot 5 \mathrm{~g} /$ calf/day (YL) or $5 \mathrm{~g} /$ calf/day (YH).

propionate ratio $(P<0 \cdot 001)$ were decreased with $\mathrm{YH}$ and $\mathrm{YL}$ diets compared with the Control diet (Table 3).

Increased plasmatic total protein $(P=0 \cdot 004)$, globulin $(P=0 \cdot 004)$ and glucose $(P<0 \cdot 001)$ concentrations were observed in calves fed $\mathrm{YL}$ and $\mathrm{YH}$ diets. On the contrary, cholesterol and triglycerides concentrations in plasma were decreased $(P<0 \cdot 001)$ with $\mathrm{YL}$ and $\mathrm{YH}$ diets. No effect of $S$. cerevisiae was observed on blood albumin, urea-N, GOT and GPT concentrations (Table 4).

\section{Growth performance}

At birth and at 28 days of age, there were no significant differences in BW among calves fed the different diets. After day 42, calves fed $\mathrm{YH}$ and $\mathrm{YL}$ diets had increased $(P<0 \cdot 001)$ BWs compared to those fed the Control diet. As a result, calves fed $S$. cerevisiae $(\mathrm{YH}$ and $\mathrm{YL}$ diets) showed increased $(P<0 \cdot 001)$ growth rate through the whole experiment compared with those fed the Control diet (Table 5).

Faecal pathogens profile

At days 5 and 6 of the experiment, faecal shedding of Clostridium spp., E. coli and Enterobacteria spp. was significantly $(P<0 \cdot 001)$ reduced in calves fed the $\mathrm{YH}$ diet compared with those fed the Control diet. At days 42 and 70, no pathogens were detected in the faeces of calves fed the YL and YH diets (Table 6).

\section{DISCUSSION}

Feed intake and digestibility

Saccharomyces cerevisiae supplementation increased intake of solid feed by calves by about 15-19\% just before weaning (at day 90 of the experiment). Moreover, $S$. cerevisiae increased the average daily hay intake by $20-23 \%$ throughout the last 5 weeks before weaning. Feed intake depends on many factors, including palatability, fibre digestion and digesta flow rate. Saccharomyces cerevisiae may have a flavouring effect and can induce the production of glutamic acid, which can benefit the taste of feed (Newbold et al. 1996).

The increased intake may also be due to enhanced rumen fermentation (Newbold et al. 1996) and improved fibre digestion, which might decrease rumen fill (Patra 2012). Within the rumen, live yeasts (e.g. S. cerevisiae) are metabolically active at least for a short time (Kung et al. 1997), thereby affecting ruminal fermentation and stimulating microbial growth (Al Ibrahim et al. 2010). Such changes within the rumen are often associated with increased dietary nutrient (e.g. fibre) digestion (Guedes et al. 2008). In response to an increased feed intake of $S$. cerevisiae supplemented diets, animals grew faster from week 6 onwards. At the end of the experiment calves in the $S$. cerevisiae supplemented groups had reached a greater BW, and thus the increased feed intake at 90 day of age could be attributed to both a possible stimulating effect of the $S$. cerevisiae and as 
Table 3. Ruminal fermentation in crossbred Friesian calves fed diets supplemented with different levels of Saccharomyces cerevisiae $(n=8$ per each group)

\begin{tabular}{|c|c|c|c|c|c|c|c|}
\hline & \multicolumn{3}{|c|}{ Diets* } & \multirow[b]{2}{*}{ S.E.M. } & \multicolumn{3}{|c|}{$P$ value } \\
\hline & Control & $\mathrm{YL}$ & $\mathrm{YH}$ & & Diet effects & Linear & Quadratic \\
\hline \multicolumn{8}{|l|}{$\mathrm{pH}$} \\
\hline $0 \mathrm{~h}$ & $6 \cdot 7$ & $6 \cdot 7$ & $6 \cdot 7$ & $0 \cdot 03$ & $0 \cdot 804$ & $0 \cdot 853$ & $0 \cdot 531$ \\
\hline $3 \mathrm{~h}$ & $6 \cdot 4$ & $6 \cdot 4$ & $6 \cdot 4$ & $0 \cdot 02$ & 0.930 & $0 \cdot 745$ & $0 \cdot 851$ \\
\hline $6 \mathrm{~h}$ & $6 \cdot 6$ & $6 \cdot 6$ & $6 \cdot 6$ & $0 \cdot 03$ & $0 \cdot 851$ & $0 \cdot 806$ & $0 \cdot 613$ \\
\hline \multicolumn{8}{|l|}{ Ammonia-N (mm/l) } \\
\hline $0 \mathrm{~h}$ & $10 \cdot 3$ & $9 \cdot 0$ & $8 \cdot 9$ & $0 \cdot 16$ & $<0 \cdot 001$ & $<0 \cdot 001$ & $0 \cdot 007$ \\
\hline $3 \mathrm{~h}$ & $12 \cdot 4$ & $10 \cdot 5$ & $10 \cdot 5$ & $0 \cdot 14$ & $<0 \cdot 001$ & $<0 \cdot 001$ & $<0 \cdot 001$ \\
\hline $6 \mathrm{~h}$ & $11 \cdot 2$ & $9 \cdot 5$ & $9 \cdot 5$ & $0 \cdot 16$ & $<0 \cdot 001$ & $<0 \cdot 001$ & $<0 \cdot 001$ \\
\hline \multicolumn{8}{|c|}{ Total volatile fatty acids (VFA; mM/l) } \\
\hline $0 \mathrm{~h}$ & 102 & 106 & 106 & $0 \cdot 5$ & $<0 \cdot 001$ & $<0 \cdot 001$ & $0 \cdot 005$ \\
\hline $3 \mathrm{~h}$ & 105 & 108 & 110 & $0 \cdot 5$ & $<0 \cdot 001$ & $<0 \cdot 001$ & $0 \cdot 123$ \\
\hline $6 \mathrm{~h}$ & 102 & 106 & 107 & $0 \cdot 5$ & $<0 \cdot 001$ & $<0 \cdot 001$ & $0 \cdot 037$ \\
\hline \multicolumn{8}{|c|}{ Individual VFA at $3 \mathrm{~h}$ after feeding $(\mathrm{mm} / \mathrm{l})$} \\
\hline Acetic acid & 60 & 61 & 61 & $0 \cdot 3$ & $0 \cdot 030$ & $0 \cdot 015$ & $0 \cdot 237$ \\
\hline Propionic acid & 21 & 23 & 23 & $0 \cdot 4$ & $<0 \cdot 001$ & $<0 \cdot 001$ & $0 \cdot 013$ \\
\hline Butyric acid & $6 \cdot 6$ & $5 \cdot 2$ & 4.9 & $0 \cdot 38$ & 0.025 & $0 \cdot 012$ & $0 \cdot 242$ \\
\hline Acetic/propionic & $2 \cdot 95$ & $2 \cdot 64$ & $2 \cdot 63$ & $0 \cdot 041$ & $<0 \cdot 001$ & $<0 \cdot 001$ & $0 \cdot 012$ \\
\hline
\end{tabular}

* Saccharomyces cerevisiae added at $0 \mathrm{~g} /$ calf/day (Control), $2 \cdot 5 \mathrm{~g} /$ calf/day (YL) or $5 \mathrm{~g} /$ calf/day (YH).

Table 4. Blood serum parameters in crossbred Friesian calves fed diets supplemented with different levels of Saccharomyces cerevisiae ( $n=8$ per each group)

\begin{tabular}{|c|c|c|c|c|c|c|c|}
\hline & \multicolumn{3}{|c|}{ Diets* } & \multirow[b]{2}{*}{ S.E.M. } & \multicolumn{3}{|c|}{$P$ value } \\
\hline & Control & $\mathrm{YL}$ & $\mathrm{YH}$ & & Diet effects & Linear & Quadratic \\
\hline Total protein (g/dl) & $6 \cdot 49$ & $7 \cdot 34$ & $7 \cdot 59$ & $0 \cdot 180$ & $0 \cdot 004$ & $0 \cdot 002$ & $0 \cdot 239$ \\
\hline Albumin (g/dl) & $3 \cdot 90$ & $4 \cdot 30$ & $4 \cdot 30$ & $0 \cdot 120$ & $0 \cdot 094$ & $0 \cdot 061$ & $0 \cdot 236$ \\
\hline Globulin (g/dl) & $2 \cdot 59$ & $3 \cdot 04$ & $3 \cdot 29$ & $0 \cdot 117$ & $0 \cdot 004$ & $0 \cdot 001$ & $0 \cdot 520$ \\
\hline Glucose (mg/dl) & 77 & 85 & 85 & $0 \cdot 8$ & $<0 \cdot 001$ & $<0 \cdot 001$ & $0 \cdot 001$ \\
\hline Cholesterol (mg/dl) & 55 & 45 & 43 & $0 \cdot 6$ & $<0 \cdot 001$ & $<0 \cdot 001$ & $<0 \cdot 001$ \\
\hline Triglycerides (mg/dl) & 31 & 27 & 26 & $0 \cdot 4$ & $<0 \cdot 001$ & $<0 \cdot 001$ & $0 \cdot 001$ \\
\hline Urea-N (mg/dl) & 22 & 22 & 21 & $0 \cdot 4$ & $0 \cdot 380$ & $0 \cdot 233$ & $0 \cdot 484$ \\
\hline Glutamate-oxaloacetate transaminase (U/l) & 29 & 28 & 28 & $0 \cdot 5$ & $0 \cdot 294$ & $0 \cdot 136$ & $0 \cdot 692$ \\
\hline Glutamate-pyruvate transaminase (U/l) & 19 & 20 & 19 & $0 \cdot 4$ & $0 \cdot 670$ & 0.923 & $0 \cdot 383$ \\
\hline
\end{tabular}

* Saccharomyces cerevisiae added at $0 \mathrm{~g} /$ calf/day (Control), $2 \cdot 5 \mathrm{~g} /$ calf/day (YL) or $5 \mathrm{~g} /$ calf/day (YH).

the consequence of animals with a greater weight eating more feed. The increased intake of solid feed, in particular of forage, in $S$. cerevisiae supplemented calves at weaning may lead to an increased intake capacity of the growing animal, being able to eat more feed after weaning and thus to grow faster. Galvão et al. (2005) observed increased grain intake by calves when fed live $S$. cerevisiae during the preweaning but not at the post-weaning period.
Fibre digestibility was increased by $18-21 \%$ when calves received the $S$. cerevisiae, supporting the idea of modified and improved ruminal conditions in response to $S$. cerevisiae supplementation. Saccharomyces cerevisiae has the ability to scavenge oxygen on the surfaces of freshly ingested feeds and reduce the redox potential within the rumen (Chaucheyras-Durand et al. 2008), creating a more anaerobic environment favouring the activity of 
Table 5. Weights $(\mathrm{kg})$ and daily gains (g/day) in crossbred Friesian calves fed diets supplemented with different levels of Saccharomyces cerevisiae ( $n=8$ per each group)

\begin{tabular}{lrrrrrrrrr}
\hline \hline & \multicolumn{3}{c}{ Diets* } & & \multicolumn{3}{c}{$P$ value } \\
\cline { 2 - 3 } & Control & YL & YH & & S.E.M. & Diet effects & Linear & Quadratic \\
\hline Birth weight & 37 & 36 & 36 & $0 \cdot 6$ & & $0 \cdot 602$ & $0 \cdot 341$ & $0 \cdot 708$ \\
Body weight at d 28 & 47 & 48 & 49 & $0 \cdot 8$ & & $0 \cdot 192$ & $0 \cdot 074$ & $0 \cdot 735$ \\
d 42 & 54 & 58 & 58 & $0 \cdot 9$ & & $0 \cdot 010$ & $0 \cdot 004$ & $0 \cdot 168$ \\
d 56 & 58 & 63 & 65 & $1 \cdot 0$ & $<0 \cdot 001$ & $<0 \cdot 001$ & $0 \cdot 140$ \\
d 70 & 65 & 71 & 72 & $1 \cdot 0$ & $<0 \cdot 001$ & $<0 \cdot 001$ & $0 \cdot 056$ \\
d 84 & 70 & 79 & 81 & $0 \cdot 9$ & $<0 \cdot 001$ & $<0 \cdot 001$ & $0 \cdot 013$ \\
Average daily gain (calculated by regression) & 399 & 534 & 552 & $7 \cdot 1$ & $<0 \cdot 001$ & $<0 \cdot 001$ & $<0 \cdot 001$ \\
\hline \hline
\end{tabular}

* Saccharomyces cerevisiae added at $0 \mathrm{~g} /$ calf/day (Control), $2 \cdot 5 \mathrm{~g} /$ calf/day (YL) or $5 \mathrm{~g} /$ calf/day (YH).

Table 6. Faecal pathogenic bacteria (log values) in crossbred Friesian calves fed diets supplemented with different levels of Saccharomyces cerevisiae ( $n=8$ per each group)

\begin{tabular}{|c|c|c|c|c|c|c|c|}
\hline & \multicolumn{3}{|c|}{ Diets* } & \multirow[b]{2}{*}{ S.E.M. } & \multicolumn{3}{|c|}{$P$ value } \\
\hline & Control & $Y L$ & $\mathrm{YH}$ & & Diet effects & Linear & Quadratic \\
\hline Clostridium spp. at d 5 & $3 \cdot 35$ & $1 \cdot 85$ & $1 \cdot 69$ & $0 \cdot 187$ & $<0 \cdot 001$ & $<0 \cdot 001$ & 0.004 \\
\hline d 6 & $2 \cdot 94$ & $0 \cdot 45$ & $0 \cdot 50$ & $0 \cdot 251$ & $<0 \cdot 001$ & $<0 \cdot 001$ & $<0 \cdot 001$ \\
\hline d 42 & $1 \cdot 25$ & $0 \cdot 00$ & $0 \cdot 00$ & 0.062 & $<0 \cdot 001$ & $<0 \cdot 001$ & $<0 \cdot 001$ \\
\hline d 70 & $1 \cdot 05$ & $0 \cdot 00$ & $0 \cdot 00$ & 0.026 & $<0 \cdot 001$ & $<0 \cdot 001$ & $<0 \cdot 001$ \\
\hline E. coli at d 5 & $3 \cdot 59$ & $2 \cdot 13$ & $2 \cdot 09$ & $0 \cdot 203$ & $<0 \cdot 001$ & $<0 \cdot 001$ & $0 \cdot 004$ \\
\hline d 6 & $3 \cdot 28$ & $0 \cdot 66$ & $0 \cdot 32$ & $0 \cdot 222$ & $<0 \cdot 001$ & $<0 \cdot 001$ & $<0 \cdot 001$ \\
\hline d 42 & $2 \cdot 99$ & $0 \cdot 00$ & 0.00 & 0.036 & $<0 \cdot 001$ & $<0 \cdot 001$ & $<0 \cdot 001$ \\
\hline d 70 & $2 \cdot 58$ & $0 \cdot 00$ & 0.00 & 0.074 & $<0 \cdot 001$ & $<0 \cdot 001$ & $<0 \cdot 001$ \\
\hline Enterobacteria spp. at d 5 & $3 \cdot 42$ & $2 \cdot 41$ & $1 \cdot 70$ & $0 \cdot 301$ & $<0 \cdot 001$ & $<0 \cdot 001$ & $0 \cdot 664$ \\
\hline d 6 & $3 \cdot 52$ & $0 \cdot 81$ & 0.00 & $0 \cdot 293$ & $<0 \cdot 001$ & $<0 \cdot 001$ & $0 \cdot 008$ \\
\hline d 42 & $2 \cdot 36$ & $0 \cdot 00$ & 0.00 & $0 \cdot 198$ & $<0 \cdot 001$ & $<0 \cdot 001$ & $<0 \cdot 001$ \\
\hline d 70 & $1 \cdot 30$ & $0 \cdot 00$ & 0.00 & $0 \cdot 175$ & $<0 \cdot 001$ & $<0 \cdot 001$ & $0 \cdot 003$ \\
\hline
\end{tabular}

* Saccharomyces cerevisiae added at $0 \mathrm{~g} /$ calf/day (Control), $2.5 \mathrm{~g} /$ calf/day (YL) or $5 \mathrm{~g} /$ calf/day (YH).

ruminal microorganisms (Newbold et al. 1996). Saccharomyces cerevisiae can provide some soluble compounds, such as organic acids, amino acids, peptides or vitamins that might be essential growth factors for ruminal bacteria, thus stimulating microbial growth (Newbold et al. 1996; Chaucheyras-Durand et al. 2008). Feeding S. cerevisiae has been shown to increase the numbers of total bacteria (Koul et al. 1998) and cellulolytic bacteria (Harrison et al. 1988) in the rumen.

\section{Ruminal fermentation}

Saccharomyces cerevisiae was provided with the milk fed to the calves. Owing to the closure of the reticular groove, in pre-ruminants milk flows directly from the oesophagus to the abomasum, thus bypassing the rumen. It may be expected that during the first weeks of the experiment, when calves were milkfed, the benefits of the $S$. cerevisiae can be attributed to their effects on the intestinal microbiota. The functioning of the reticular groove is less efficient with calf age and the transition to solid feed, leading to the development of the rumen and the onset of microbial fermentation. Thus, it is possible that in pre-weaned calves some of the liquid ingested enters the rumen and the $S$. cerevisiae is incorporated into the ruminal microbiota. Regardless of the way that $S$. cerevisiae enters the rumen, the results of the current study clearly show that in those calves supplemented with 
S. cerevisiae, ruminal fermentation was modulated with some beneficial effects on calf performance. With no effect on ruminal $\mathrm{pH}, S$. cerevisiae supplementation at low and high doses increased VFA concentration at different times post-feeding, also in particular the concentrations of propionate and acetate. The ruminal $\mathrm{pH}$ of all calves was above $6 \cdot 0$, suggesting the absence of ruminal acidosis. The absence of an effect of $S$. cerevisiae supplementation on ruminal $\mathrm{pH}$ is mainly due to higher ruminal $\mathrm{pH}$ above 6.0 during all times post-feeding. Enjalbert et al. (1999) and Al Ibrahim et al. (2010) reported that when ruminal $\mathrm{pH}$ is above $6 \cdot 0$, then $S$. cerevisiae supplementation had little or no effect on ruminal $\mathrm{pH}$. Increased total VFA caused increased propionate and acetate together. The increased concentration of ruminal acetate in the supplemented calves was in agreement with Al Ibrahim et al. (2010), and may be related to the stimulating effect of $S$. cerevisiae on growth or activity of fibre-degrading microorganisms in the rumen (Elghandour et al. 2015). The increased concentration of ruminal propionate may be due to the increased ingestion of concentrate feed when calves received the $S$. cerevisiae. Guedes et al. (2008) observed increased acetate and propionate concentrations in the ruminal fluid of non-lactating cows supplemented with $S$. cerevisiae.

Decreased ruminal ammonia- $N$ concentrations with $S$. cerevisiae supplemented diets suggests some changes in the $\mathrm{N}$ metabolism of rumen microorganisms. It is plausible that proteolytic bacteria numbers and their activity is reduced in the rumen of animals receiving the $S$. cerevisiae, as reported in the in vitro study of Chaucheyras-Durand et al. (2005). With a suitable balance between soluble $\mathrm{N}$ and carbohydrate supply, $S$. cerevisiae could enhance microbial growth and decrease $\mathrm{N}$ loss. Moreover, increased ammonia$\mathrm{N}$ incorporation into microbial protein (Erasmus et al. 1992), which may be the result of enhanced microbial activity (Williams et al. 1991), is another probable reason (Al Ibrahim et al. 2010). The current results are in line with those of Al Ibrahim et al. (2010).

\section{Blood chemistry}

Blood chemistry was affected positively with $S$. cerevisiae supplementation (Galip 2006). Saccharomyces cerevisiae caused increased total protein and globulin concentrations in plasma. This suggests that protein utilization might have been improved with the addition of $S$. cerevisiae. This can be related to increased dietary CP digestibility, by 4-9\% with S. cerevisiae fed at low and high doses, respectively. In his experiment, Galip (2006) observed increased total protein and urea concentrations with decreasing triglycerides and without affecting albumin, cholesterol and liver enzymes with $S$. cerevisiae supplementation.

The higher serum glucose with $S$. cerevisiae supplemented calves may be due to greater propionate production in the rumen. Blood glucose concentration depends mainly on energy consumption and utilization by tissues. In calves fed $S$. cerevisiae, increased intake of the starter concentrate could favour the production of propionate in the rumen thus increasing glucose availability from gluconeogenesis. Galvão et al. (2005) reported an increased glucose concentration in the plasma of calves receiving $S$. cerevisiae as a result of increased energy intake (Hammon et al. 2002).

One important observation was the decreased blood cholesterol and triglyceride concentrations in the plasma of animals receiving $S$. cerevisiae. Kowalik et al. (2012) obtained similar results. The decreased total cholesterol and triglyceride concentrations in blood could be caused by some positive changes in rumen fermentation and populations of ruminal bacteria and protozoa with $S$. cerevisiae supplementation. Pysera \& Opałka (2001) explained that the change in rumen VFA, particularly propionate, butyrate and valerate acids, is responsible for the decreased synthesis of cholesterol and triglycerides in the liver cells. Moreover, the cell wall of $S$. cerevisiae is rich in $\beta$-glucans content which, according to Nicolosi et al. (1999), could reduce blood total cholesterol and triglycerides.

\section{Calf growth performance}

The initial BWs of all calves were almost the same with no differences among experimental groups, reflecting the random assignment of the diets to the calves at the beginning of the experiment. Body weight was increased in calves fed the diets supplemented with $S$. cerevisiae from week 6 and thereafter until the end of the trial. Average weight gain was 34$38 \%$ greater in calves fed $S$. cerevisiae than in those fed the Control diet. Increased growth rate may be due to a more efficient feed utilization and conversion rate in pre-weaned calves supplemented with $S$. cerevisiae. The increased feed intake and digestibility and the more favourable rumen fermentation with $S$. cerevisiae supplementation would benefit rumen health 
and development (Pal et al. 2010), and thus calves are more likely to reach their full growth potential. Issakowicz et al. (2013) and Kamal et al. (2013) observed that $S$. cerevisiae supplementation caused increased daily weight gain in lambs and kids, respectively.

\section{Faecal pathogenic bacteria}

Faecal pathogenic bacteria disappeared after 42 days of feeding $S$. cerevisiae at low and high doses. This is an important outcome of feeding $S$. cerevisiae to preweaned calves with low immunity and high incidence of diarrhoea and mortality rate. The microbial ecology of the gastrointestinal tract impacts health and performance of animals (Agarwal et al. 2002). The effect of yeast may be due to the ability of live $S$. cerevisiae to produce some substances that are inhibitory for pathogenic bacteria (Bach et al. 2003). Yeasts such as $S$. cerevisiae can eliminate or reduce numbers of undesirable microorganisms (bacteria, protozoa) through competition for sites of colonization in the gut, by production of inhibitory metabolites (Zhao et al. 1998), or by favouring specific groups of microorganisms within the gastrointestinal tract that are beneficial to the host (Yoon \& Stern 1995). In addition, $S$. cerevisiae can be irreversibly bound to pathogenic bacteria such as E. coli and Salmonella due to the presence of lectin sites for mannose-sensitive adhesion in the outer membrane of the yeast cell wall (Gedek 1999). Moreover, S. cerevisiae can reduce numbers of pathogenic bacteria indirectly by improving calves' immunity status, due to the contents of some cell wall material such as mannan and glucan (approximately $350 \mathrm{~g}$ mannan/kg DM and $300 \mathrm{~g}$ glucan/kg DM) (Reed \& Nagodawithana 1991). Both of these substances are normally not digested or absorbed in the small intestine (Newman 1994), with an ability for pathogen removal from the digestive system through offering competitive binding site options for Gram-negative and Gram-positive bacteria (Suzuki et al. 1990) and blocking bacterial attachment to the intestinal epithelium (Newman 1994). Bach et al. (2003) observed that treatment with S. cerevisiae completely eradicated $10^{4} \mathrm{CFU}$ of $E$. coli/ml in vitro within $48 \mathrm{~h}$ of incubation.

Another probable reason is the presence of some soluble products present in $S$. cerevisiae. Jensen et al. (2007) showed the ability of these products to inhibit microbial growth and to modulate the immune system. It has been suggested that feeding glucan improves neutrophil chemotaxis and respiratory burst activity (Murphy et al. 2007), and this might have enhanced phagocytic activity of neutrophils against pathogenic bacteria (Magalhães et al. 2008). Feeding S. cerevisiae to dairy calves improved health and survival of calves reducing morbidity and mortality (Magalhães et al. 2008).

It can be concluded that daily administration of $S$. cerevisiae at 2.5 and $5.0 \mathrm{~g}$ per animal to milk-fed calves increases the intake and digestibility of solid feed (concentrate and hay). Saccharomyces cerevisiae supplementation results in increased weight gain, enhanced ruminal fermentation at weaning and improved health (based on blood chemistry and faecal shedding of pathogenic bacteria) of preweaning calves. These effects can be observed with a daily dose of $2.5 \mathrm{~g} S$. cerevisiae per calf, with no further improvement by increasing the daily dose to 5 g per calf.

\section{REFERENCES}

Agarwal, N., Kamra, D. N., Chaudhary, L. C., Agarwal, I., SaHOO, A. \& PAthaK, N. N. (2002). Microbial status and rumen enzyme profile of crossbred calves fed on different microbial feed additives. Letters in Applied Microbiology 34, 329-336.

Ahmed, M.H., Elghandour, M.M.Y., Salem, A.Z.M., Zewell, H. S., Kholif, A. E., Klieve, A. V. \& Abdelrassol, A. M. A. (2015). Influence of Trichoderma reesei or Saccharomyces cerevisiae on performance, ruminal fermentation, carcass characteristics and blood biochemistry of lambs fed Atriplex nummularia and Acacia saligna mixture. Livestock Science 180, 90-97.

Al Ibrahim, R. M., Kelly, A. K., O'Grady, L., Gath, V.P., McCarney, C. \& Mulligan, F.J. (2010). The effect of body condition score at calving and supplementation with Saccharomyces cerevisiae on milk production, metabolic status, and rumen fermentation of dairy cows in early lactation. Journal of Dairy Science 93, 5318-5328.

ANNISON, E. F. (1954). Some observations on volatile fatty acids in the sheep's rumen. Biochemical Journal 57, 400-405.

AOAC (1997). Official Methods of Analysis of the Association of Official Analytical Chemist, Vol. 1, 16th edn, Washington, DC: Association of Official Analytical Chemists.

Bach, S. J., McAllister, T. A., Veira, D. M., Gannon, V. P. J. \& Holley, R. A. (2003). Effects of a Saccharomyces cerevisiae feed supplement on Escherichia coli O157:H7 in ruminal fluid in vitro. Animal Feed Science and Technology 104, 179-189.

Cedillo, J., Vázquez-Armijo, J. F., GonzÁlez-Reyna, A., Salem, A.Z.M., Kholif, A. E., Hernández-MeléndeZ, J., Martínez-González, J.C., De Oca Jiménez, R. M., Rivero, N. \& López, D. (2014). Effects of different doses 
of Salix babylonica extract on growth performance and diet in vitro gas production in Pelibuey growing lambs. Italian Journal of Animal Science 13, 609-613. Available from: http://dx.doi.org/10.4081/ijas.2014.3165.

Chaucheyras-Durand, F. \& Fonty, G. (2001). Establishment of cellulolytic bacteria and development of fermentative activities in the rumen of gnotobiotically-reared lambs receiving the microbial additive Saccharomyces cerevisiae CNCM 1-1077. Reproduction, Nutrition, Development 41, 57-68.

Chaucheyras-Durand, F. \& Fonty, G. (2002). Influence of a probiotic yeast (Saccharomyces cerevisiae CNCM I1077) on microbial colonization and fermentations in the rumen of newborn lambs. Microbial Ecology in Health and Disease 14, 30-36.

Chaucheyras-Durand, F., MasséGlia, S. \& Fonty, G. (2005). Effect of the microbial feed additive Saccharomyces cerevisiae $\mathrm{CNCM} \mathrm{I-1077} \mathrm{on} \mathrm{protein} \mathrm{and} \mathrm{peptide} \mathrm{degrading} \mathrm{ac-}$ tivities of rumen bacteria grown in vitro. Current Microbiology 50, 96-101.

Chaucheyras-Durand, F., Walker, N. D. \& Bach, A. (2008). Effects of active dry yeasts on the rumen microbial ecosystem: past, present and future. Animal Feed Science and Technology 145, 5-26.

Elghandour, M.M.Y., Salem, A.Z.M., Martínez Castañeda, J. S., Camacho, L. M., Kholif, A. E. \& VázQuez Chagoyán, J. C. (2015). Direct-fed microbes: a tool for improving the utilization of low quality roughages in ruminants. Journal of Integrative Agriculture 14, 526-533.

Enjalbert, F., Garrett, J. E., Moncoulon, R., Bayourthe, C. \& Chicoteau, P. (1999). Effects of yeast culture (Saccharomyces cerevisiae) on ruminal digestion in non-lactating dairy cows. Animal Feed Science and Technology 76, 195-206.

Erasmus, L. J., Botha, P. M. \& Kistner, A. (1992). Effect of yeast culture supplement on production, rumen fermentation, and duodenal nitrogen flow in dairy cows. Journal of Dairy Science 75, 3056-3065.

FASS (2010). Guide for the Care and Use of Agricultural Animals in Agricultural Research and Teaching, 3rd edn. Champaign, IL, USA: Federation of Animal Science Society.

Ferret, A., Plaixats, J., Caja, G. \& Gasa, J., Prió, P. (1999). Using markers to estimate apparent dry matter digestibility, faecal output and dry matter intake in dairy ewes fed Italian ryegrass hay or alfalfa hay. Small Ruminant Research 33, 145-152.

GALIP, N. (2006). Effect of supplemental yeast culture and sodium bicarbonate on ruminal fermentation and blood variables in rams. Journal of Animal Physiology and Animal Nutrition 90, 446-452.

Galvão, K. N., Santos, J. E. P., Coscioni, A., Villaseñor, M., Sischo, W. M. \& Berge, A. C. B. (2005). Effect of feeding live yeast products to calves with failure of passive transfer on performance and patterns of antibiotic resistance in fecal Escherichia coli. Reproduction, Nutrition, Development 45, 427-440.

García-González, R., López, S., Fernández, M., Bodas, R. \& GonzÁlez, J. S. (2008). Screening the activity of plants and spices for decreasing ruminal methane production in vitro. Animal Feed Science and Technology 147, 36-52.
Gedek, B. R. (1999). Adherence of Escherichia coli serogroup 0157 and the Salmonella typhimurium mutant DT 104 to the surface of Saccharomyces boulardii. Mycoses 42, 261-264.

Guedes, C. M., Gonçalves, D., Rodrigues, M. A. M. \& DiasDA-Silva, A. (2008). Effects of a Saccharomyces cerevisiae yeast on ruminal fermentation and fibre degradation of maize silages in cows. Animal Feed Science and Technology 145, 27-40.

Hammon, H. M., Schiessler, G., Nussbaum, A. \& Blum, J.W. (2002). Feed intake patterns, growth performance, and metabolic and endocrine traits in calves fed unlimited amounts of colostrum and milk by automate, starting in the neonatal period. Journal of Dairy Science 85, 3352-3362.

Harrison, G. A., Hemken, R. W., Dawson, K. A., Harmon, R. J. \& BARKER, K.B. (1988). Influence of addition of yeast culture supplement to diets of lactating cows on ruminal fermentation and microbial population. Journal of Dairy Science 71, 2967-2975.

Issakowicz, J., Bueno, M. S., Sampaio, A. C. K. \& Duarte, K. M. R. (2013). Effect of concentrate level and live yeast (Saccharomyces cerevisiae) supplementation on Texel lamb performance and carcass characteristics. Livestock Science 155, 44-52.

Jensen, G. S., Hart, A. N. \& Schauss, A. G. (2007). An anti-inflammatory immunogen from yeast culture induces activation and alters chemokine receptor expression on human natural killer cells and B lymphocytes in vitro. Nutrition Research 27, 327-335.

Kamal, R., Dutt, T., Singh, S., Kamra, D. N., Patel, M., Choudhary, L.C., Agarwal, N., Kumar, S. \& Islam, M. (2013). Effect of live Saccharomyces cerevisiae (NCDC49) supplementation on growth performance and rumen fermentation pattern in local goat. Journal of Applied Animal Research 41, 285-288.

Kholif, A. E., Gouda, G. A., Morsy, T. A., Salem, A. Z. M., LopeZ, S. \& KHOLIF, A. M. (2015). Moringa oleifera leaf meal as a protein source in lactating goat's diets: feed intake, digestibility, ruminal fermentation, milk yield and composition, and its fatty acids profile. Small Ruminant Research 129, 129-137.

Koul, V., Kumar, U., Sareen, V. K. \& Singh, S. (1998). Mode of action of yeast culture (Yea-Sacc 1026) for stimulation of rumen fermentation in buffalo calves. Journal of the Science of Food and Agriculture 77, 407-413.

Kowalik, B., Skomiat, J., Pają, J. J., Taciak, M., Majewska, M. \& BEtżECKI, G. (2012). Population of ciliates, rumen fermentation indicators and biochemical parameters of blood serum in heifers fed diets supplemented with yeast (Saccharomyces cerevisiae) preparation. Animal Science Papers \& Reports 30, 329-338.

Kung, L., Jr., Kreck, E. M., Tung, R.S., Hession, A. O., Sheperd, A. C., Cohen, M. A., Swain, H. E. \& Leedle, J. A. Z. (1997). Effects of a live yeast culture and enzymes on in vitro ruminal fermentation and milk production of dairy cows. Journal of Dairy Science 80, 2045-2051.

LANGFORd, F. M., Weary, D. M. \& Fisher, L. (2003). Antibiotic resistance in gut bacteria from dairy calves: a dose response to the level of antibiotics fed in milk. Journal of Dairy Science 86, 3963-3966. 
Lesmeister, K. E., Heinrichs, A. J. \& Gabler, M. T. (2004). Effects of supplemental yeast (Saccharomyces cerevisiae) culture on rumen development, growth characteristics, and blood parameters in neonatal dairy calves. Journal of Dairy Science 87, 1832-1839.

Magalhães, V.J.A., Susca, F., Lima, F.S., Branco, A. F., YoOn, I. \& SAntos, J. E. P. (2008). Effect of feeding yeast culture on performance, health, and immunocompetence of dairy calves. Journal of Dairy Science 91, 1497-1509.

Morsy, T. A., Kholif, A. E., Kholif, S. M., Kholif, A. M., Sun, X. \& SALEM, A. Z. M. (2016). Effects of two enzyme feed additives on digestion and milk production in lactating Egyptian buffaloes. Annals of Animal Science 16, 209-222.

Murphy, E. A., Davis, J. M., Brown, A. S., Carmichael, M. D., Ghaffar, A. \& MAyer, E.P. (2007). Oat $\beta$-glucan effects on neutrophil respiratory burst activity following exercise. Medicine \& Science in Sports \& Exercise 39, 639-644.

National Research Council (2001). Nutrient Requirements of Dairy Cattle, 7th revised edn. Washington, DC: The National Academy Press.

Newbold, C. J., Wallace, R. J. \& Mclntosh, F.M. (1996). Mode of action of the yeast Saccharomyces cerevisiae as a feed additive for ruminants. British Journal of Nutrition 76, 249-261.

Newman, K. E. (1994). Mannan-oligosaccharides: Natural polymers with significant impact on the gastrointestinal microflora and the immune system. In Proceedings of Alltech's 10th Annual Symposium (Eds T. P. Lyons \& K. A. Jacques), pp. 167-174. Nottingham, UK: Nottingham University Press.

Nicolosi, R., Bell, S. J., Bistrian, B. R., Greenberg, I., Forse, R. A. \& BlackBuRN, G. L. (1999). Plasma lipid changes after supplementation with $\beta$-glucan fiber from yeast. American Journal of Clinical Nutrition 70, 208-212.

Oxoid (1985). Oxoid Manual of Dehydrated Culture Media, Ingredients and other Laboratory Services. Basingstoke, UK: Oxoid.

Pal, K., Paul, S. K., Bhunia, T., Pakhira, M. C., Biswas, P. \& PAtRA, A. K. (2010). Responses of addition of yeast (Saccharomyces cerevisiae) from rice distillers grains with solubles with or without trace minerals on the performance of Black Bengal kids. Small Ruminant Research 94, 45-52.

PATRA, A. K. (2012). The use of live yeast products as microbial feed additives in ruminant nutrition. Asian Journal of Animal and Veterinary Advances 7, 366-375.

Phillips, I., Casewell, M., Cox, T., De Groot, B., Frils, C., Jones, R., Nightingale, C., Preston, R. \& Waddell, J. (2004). Does the use of antibiotics in food animals pose a risk to human health? A critical review of published data. Journal of Antimicrobial Chemotherapy 53, 28-52.

Pysera, B. \& Opat KA, A. (2001). Lipids and lipoproteins in blood serum of calves receiving Yea-Sacc1026 dietary supplement. Journal of Animal and Feed Sciences 10, 77-82.

Reed, G. \& Nagodawithana, T. (1991). Yeast Technology, 2nd edn. New York, NY: AVI, Van Nostrand Reinhold Publ.

Rojo, R., Kholif, A. E., Salem, A. Z. M., Elghandour, M. M. Y., Odongo, N.E., Montes De Oca, R., Rivero, N. \& Atonso, M. U. (2015). Influence of cellulase addition to dairy goat diets on digestion and fermentation, milk production and fatty acid content. Journal of Agricultural Science, Cambridge 153, 1514-1523.

RusSeLL, J. B. \& HouliHAN, A. J. (2003). Ionophore resistance of ruminal bacteria and its potential impact on human health. FEMS Microbiology Reviews 27, 65-74.

Salem, A.Z.M., RyenA, A. G., Elghandour, M. M. Y., Camacho, L. M., Kholif, A. E., Salazar, M. C., Domínguez, I. A., Jiménez, R.M., Almaraz, E. M., Martínez, A. G. L. \& MariezCurRena, M. A. (2014). Influence of Salix babylonica extract in combination or not with increasing levels of minerals mixture on in vitro rumen gas production kinetics of a total mixed ration. Italian Journal of Animal Science 13, 873-879.

Suzuki, T., Tanaka, H., Kinoshita, A., Oikawa, S., Osawa, M. \& YADOMAE, T. (1990). Effect of orally administered $\beta$-glucan in macrophage function in mice. International Journal of Immunopharmacology 12, 675-684.

Van Soest, P. J., Robertson, J. B. \& Lewis, B. A. (1991). Methods for dietary fiber, neutral detergent fiber, and non-starch polysaccharides in relation to animal nutrition. Journal of Dairy Science 74, 3583-3597.

Williams, P.E., Tait, C.A., InNes, G. M. \& Newbold, C. J. (1991). Effects of the inclusion of yeast culture (Saccharomyces cerevisiae plus growth medium) in the diet of dairy cows on milk yield and forage degradation and fermentation patterns in the rumen of steers. Journal of Animal Science 69, 3016-3026.

YOON, I. K. \& SteRn, M. D. (1995). Influence of direct-fed microbials on ruminal microbial fermentation and performance of ruminants: a review. Asian-Australasian Journal of Animal Sciences 8, 533-555.

Zhao, T., Doyle, M.P., Harmon, B. G., Brown, C.A., Mueller, P. O. E. \& Parks, A. H. (1998). Reduction of carriage of enterohemorrhagic Escherichia coli O157:H7 in cattle by inoculation with probiotic bacteria. Journal of Clinical Microbiology 36, 641-647. 